\title{
Environmental and economic issues concerning the use of wet scrubbers coupled to bagasse-fired boilers: a case study in the Brazilian sugarcane industry
}

\author{
Murilo Daniel de Mello Innocentini ${ }^{1}$ · Federico Giovanni Lovero ${ }^{2}$ - Ariana Silva Ferreira ${ }^{1}$ Tapas K. Das ${ }^{3}$. \\ Paolo Tronville ${ }^{2}$ iD
}

Received: 5 January 2021 / Accepted: 10 June 2021 / Published online: 18 June 2021

(c) The Author(s) 2021

\begin{abstract}
For decades, wet scrubbers have been used to control particulate matter (PM) emitted by bagasse-fired boilers in the sugarcane industry. This choice was justified by their acceptable performance in meeting environmental standards, the abundance of water resources, and the fact that their operation was simpler and less expensive than other dry cleaning operations. However, the progressive tightening of PM emission limits, as well as the need for more rational water and wastewater management in these applications, has changed this aspect of the industry. Despite the extensive technical literature on wet scrubbers, the lack of up-to-date indicators of their performance in sugarcane industries has prevented the optimization of wet scrubbing processes. This paper clearly shows that the use of wet scrubbers can result in significant water and heat losses, as well as high operating costs for wastewater treatment stations (WTSs). Mass and energy balances were determined for a typical ethanol-sugar plant operating in Brazil, which is the world's largest sugarcane producer. The key boiler and scrubber performance indicators were evaluated experimentally over the course of a crop season and were compared to the legal particulate emission and water quality requirements in Brazil. The boiler processed an average of $114.8 \mathrm{t} / \mathrm{h}$ of bagasse containing $46.8 \%$ moisture and generated $4.75 \mathrm{t}$ of gas and $28.2 \mathrm{~kg}$ of PM for each ton of dry burned bagasse. Of the total PM (ash and soot), $68 \%$ was collected as dry material in the grate, heat exchangers, and multicyclone; $25 \%$ was collected in the wet scrubber; and $7 \%$ was emitted to the atmosphere, in compliance with the Brazilian standards. The operation of the WTS linked to the gas cleaning system was inefficient, using $70 \%$ of the water to convey the dry PM retained in the boiler, heat exchangers, and multicyclone and only $30 \%$ to operate the wet scrubber. Evaporation caused the loss of $10.5 \%$ of the scrubbing water to the atmosphere. The transportation of moist cake $(7.9 \mathrm{t} / \mathrm{h}, 78 \% \mathrm{wb})$ for disposal in fields resulted in significant fuel costs and water losses. The operation of the WTS accounted for $62 \%$ of the total capital expenditure of the cleaning system, while the wet scrubber accounted for only $38 \%$. This work provides updated performance indicators and alternatives for optimizing a gas cleaning system to promote more rational water and wastewater management and savings for the sugarcane sector.
\end{abstract}

Murilo Daniel de Mello Innocentini

minnocentini@unaerp.br

Paolo Tronville

paolo.tronville@polito.it

1 Post-Graduation Program in Environmental Technology, University of Ribeirão Preto (UNAERP), Ribeirão Preto, SP 14096-900, Brazil

2 Department of Energy, Politecnico di Torino, 10129 Turin, Italy

3 School of Engineering, Saint Martin's University, Lacey, Washington 98503, USA 


\section{Graphic abstract}

Required collection efficiencyfor bagasse boilers based on the inlet PM concentration and emission limits imposed in Brazil, China, and most countries

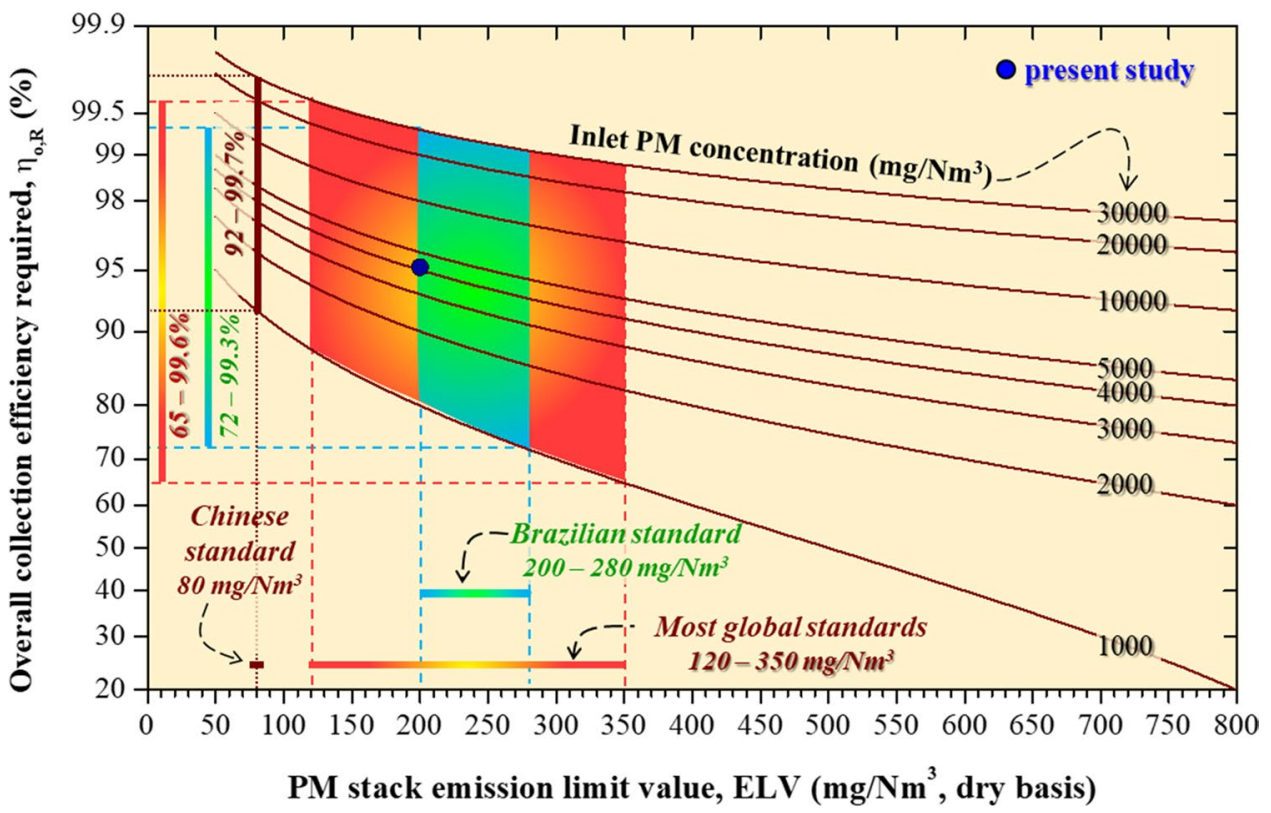

Keywords Sugarcane processing $\cdot$ Wet scrubber $\cdot$ Environmental impact $\cdot$ Water management $\cdot$ Bagasse-fired boilers $\cdot$ PM control

\section{Introduction}

Sugarcane (Saccharum officinarum) is one of the most efficient crops in the world for producing sugar, ethanol, and energy (FAO 2019). Sugarcane processing exceeded 1,840 million tons (Mt) in the 2017-2018 season, with Brazil, India, and China accounting for 63\% (Sahu 2018). Brazil alone accounted for $48 \%$ (633.3 Mt) of harvested sugarcane, as well as $26 \%\left(27.2 \mathrm{Mm}^{3}\right)$ of ethanol and $26 \%$ (37.9 $\mathrm{Mt}$ ) of global sugar production (GAIN-USDA-FAS 2018). During the same time period, Brazil produced 165.6 Mt of sugarcane bagasse, and its complete combustion in boilers and cogeneration plants produced $301 \mathrm{Mt}$ of heat energy as steam and 71.5 TWh of electric energy (EPE 2018). Proportional product and processing profiles have been reported for India (Tsiropoulos et al. 2014), South Africa (IRENA 2019), and China (Peng et al. 2014).

Despite the obvious benefits to the economy and the renewable energy matrix, the massive amount of sugarcane processing could have negative environmental consequences (Zhao and Li 2015). During fermentation, carbon dioxide is produced and released into the atmosphere at a rate of $956 \mathrm{~kg}$ per metric ton of ethanol. Vinasse, a dark brown, acidic byproduct with high organic and sulfur contents, is produced in a volume proportion of $12: 1$ to ethanol during distillation (Fuess and Garcia 2014). Furthermore, boiler and cogeneration plant operations emit up to $5 \mathrm{t}$ of flue gases into the atmosphere and produce up to $30 \mathrm{~kg}$ of particulate matter (PM; soot, char, and ash) per metric ton of burned bagasse (Teixeira et al. 2007). Figure 1 reports the overall numbers for sugarcane processing in Brazil during the 2017-2018 season.

The management of water and wastewater by sugarcane industries is a constant source of concern, especially given that the majority of Brazil's 400 ethanol plants are located above the Guarani aquifer system, one of the world's largest freshwater reservoirs. Sugar and ethanol production require large amounts of water, which could deplete this resource. The excessive use of underground freshwater by sugarcane industries, as well as the contamination of this aquifer with pesticides and process effluents, affects Brazil and neighboring countries that rely on the aquifer. Investment in best practices and reuse technologies resulted in a decrease in freshwater use from 15 to $21 \mathrm{~m}^{3} / \mathrm{t}_{\text {cane }}$ over the last four decades to $1-2 \mathrm{~m}^{3} / \mathrm{t}_{\text {cane }}$ in recent years (Moreira 2007). The target for the coming years is $0.5-1.0 \mathrm{~m}^{3} / \mathrm{t}_{\text {cane }}$, and zero discharge has been proposed, even though the target can be met by incorporating process wastewater into vinasse for irrigation of the sugarcane crop (Stone et al. 2010). 
Fig. 1 Main products and byproducts of the Brazilian sugarcane industry during the 2017-2018 season

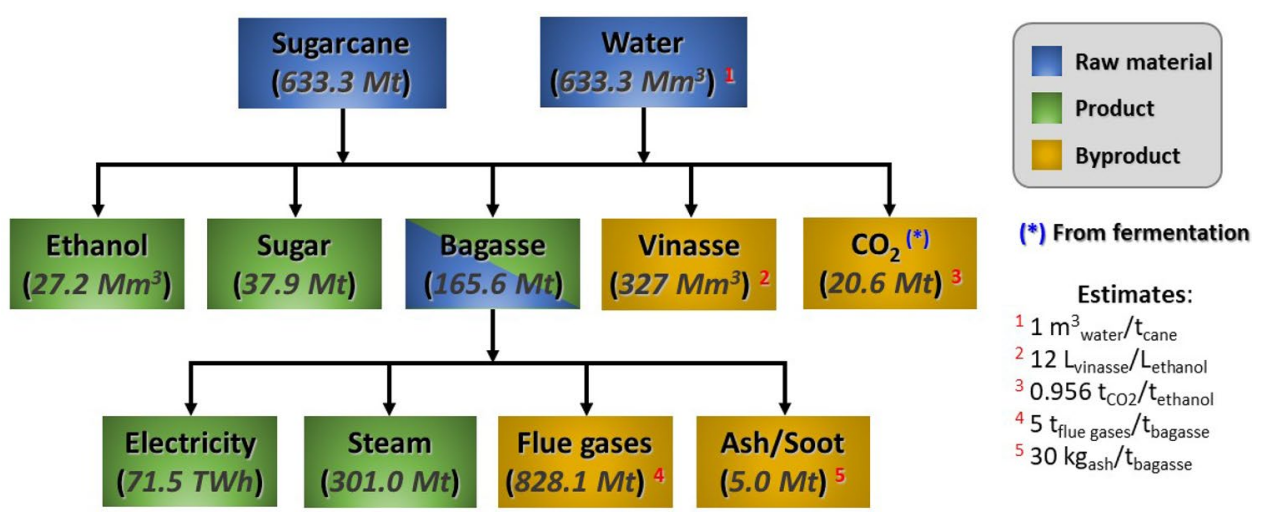

One sector of the sugarcane process that has not significantly improved in recent decades is the cleaning of the flue gases emitted from steam boilers and cogeneration plants (Mann 2017). PM is the most critical contaminant due to its high generation rate (Teixeira et al. 2007), followed by nitrogen oxides $\left(\mathrm{NO}_{x}\right)$ (Sahu et al. 2015), sulfur dioxide $\left(\mathrm{SO}_{2}\right)$, and volatile organic compounds (VOCs) (Zhang et al. 2020). A wet scrubber (spray tower and impingement types) is the most commonly used device to control PM in bagasse boilers, and it is sometimes preceded by a multicyclone (Boshoff and Yeo 1999).

Wet scrubbers have been used for decades around the world based on the assumption that water is readily available and that their operation is simpler and more inexpensive for use in sugarcane industries than are dry cleaning technologies (Singh and Shukla 2014). The PM collection efficiency of scrubbers is also reportedly sufficient to meet the current Brazilian and international emission standards (Moor 2007).

Currently, the cost of water intake for industries in Brazil is still relatively low, and wet scrubbers are used with little consideration of water and energy losses and without a thorough assessment of economic viability. However, this scenario is rapidly changing, as taxes on water intake and discharge have gradually increased in recent years, while the capital and operational costs of novel dry cleaning devices have decreased over time. Furthermore, studies have revealed the presence of dioxins and furans in bagasse combustion flue gases carrying fly ash (Yive and Tiroumalechetty 2008). Because of water recirculation, the absorption of these highly toxic and carcinogenic pollutants in the water of wet scrubbers could contaminate the entire sugarcane process and the environment (due to wastewater discharge in a field or in aquatic systems). If scrubbing water contamination is confirmed, the use of this technology may be jeopardized in the near future.

The literature on the performance of wet scrubbers in the sugarcane industry is limited and out of date. In this context, this paper describes a systematic experimental study conducted in the wet scrubbing unit of a sugarcane plant in Brazil. The water and heat balances associated with the scrubber operation were evaluated, and all losses were identified and quantified. The capital and operational costs of gas cleaning and wastewater treatment were calculated. Alternatives for reducing water demand were evaluated, allowing the mitigation of environmental impact.

\section{Experimental work}

The agroindustrial unit studied in this work is located in the Brazilian state of Minas Gerais and started operating in 2009. In the 2016-2017 season, 2,742,366 t of sugarcane was crushed; this value increased to $3,166,907 \mathrm{t}$ in the 2017-2018 season, when cogeneration reached $260 \mathrm{GWh}$ with a surplus of $160 \mathrm{GWh}$. Figure 2 shows the plant's combined stages of steam generation, gas cleaning, and water treatment.

A vertical water tube boiler with a nominal capacity of $200 \mathrm{t} / \mathrm{h}$ of steam at $490{ }^{\circ} \mathrm{C}$ and $75 \mathrm{bar}(7.5 \mathrm{MPa})$ and a nominal power of $190 \mathrm{MW}$ is part of the system. Bagasse from the milling section is pneumatically fed into the combustion chamber, where it burns partly on a fixed grate and partly in suspension due to secondary airflow. The flue gases exchange heat within the combustion chamber to produce steam and then pass through the economizer and air preheater units to raise the temperatures of the feed water and air, respectively. Following the heat exchange stages, the flue gases are cleaned by two devices in sequence: first, a multicyclone unit (with 12 parallel tangential-inlet cyclones) to remove coarse PM (char and ash) and then a low-energy scrubber (spray tower) before exhausting to the atmosphere. In Brazil, federal and state regulations require maximum emission limit values (ELVs) for this combustion source of $200 \mathrm{mg} / \mathrm{Nm}^{3}$ for $\mathrm{PM}$ and $350 \mathrm{mg} / \mathrm{Nm}^{3}$ for $\mathrm{NO}_{x}$ (on a dry basis with $8 \%$ excess $\mathrm{O}_{2}$ ) (CONAMA 2006, 2011). There is no requirement to measure $\mathrm{CO}$ for boilers with capacities greater 
Fig. 2 Combined stages of steam generation, gas cleaning, and water treatment associated with a typical bagasse-fired boiler in Brazil

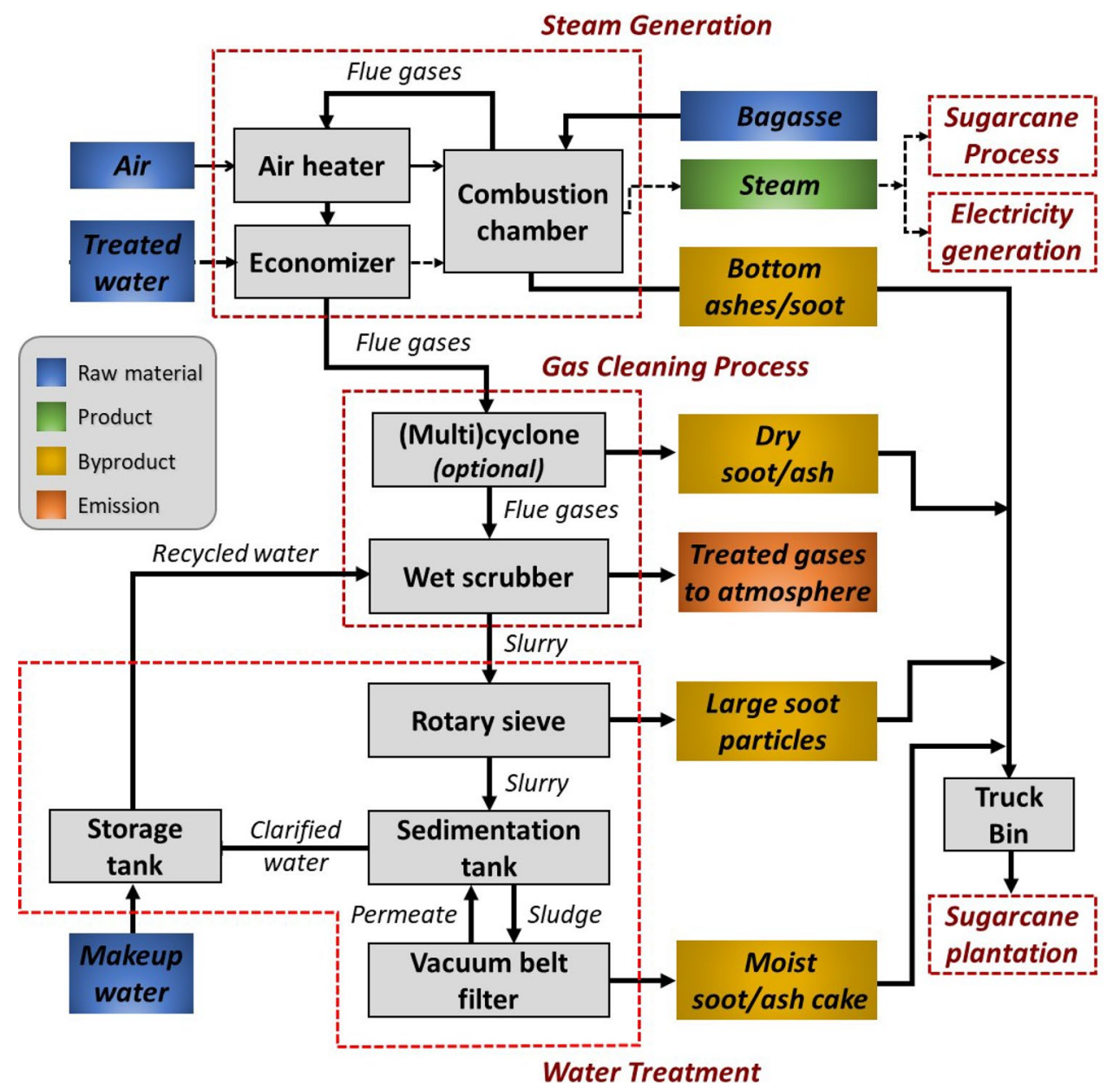

than $10 \mathrm{MW}$. Figure 3 describes the actual steam generation and flue gas cleaning devices and stages found in the production plant being analyzed.

Water is used to remove all PM retained or collected during the process. The boiler grate is steam cleaned, and the condensed slurry, which contains ash, char, and unburned bagasse, is discharged into a drainage channel with recirculating water from the treatment station. Dry particles collected in the economizer, air preheater, and multicyclone settle into the same channel, where they mix with the slurry stream leaving the spray tower scrubber. The whole slurry stream is collected in a tank and pumped to a rotary sieve at a wastewater treatment station (WTS) for coarse solid removal. The sieved slurry is treated with polymers in a sedimentation tank, and the clarified water phase is stored in a reservoir for recirculation in the process. The settling tank sludge is pumped to a continuous vacuum belt filter, where the char/ash cake is formed, dewatered, and discharged into trucks for disposal in a composting yard. The WTS is cleaned on a regular basis to remove excess sludge and to refill the water lost in the scrubber and ash cake. Figure 4 describes the wastewater treatment station in more detail.
A complete mass balance was determined for the steam generation plant to evaluate the water used to clean the flue gas. The data are based on a sugarcane crush rate of $476 \mathrm{t} / \mathrm{h}$ and a bagasse generation rate of $250 \mathrm{~kg} / \mathrm{t}$ cane. The overall heat balance in the steam generation and gas cleaning processes was also determined using experimental data from the plant as well as thermodynamic parameters and equations from the literature (Lovero 2017). The balance included the thermal energy in all solid, liquid, and gas flows, as well as the heat generated in the bagasse combustion with $30 \%$ excess air, the latent heat for the production of steam and evaporation of the scrubbing water, and the heat losses by convection to the atmosphere on the external surface of each piece of equipment. The bagasse composition used in the combustion calculations was obtained from the literature (Rein 2007) and is given as follows (dry basis): carbon, $46.5 \%$; hydrogen, $5.8 \%$; oxygen, $44.5 \%$; sulfur, $0.05 \%$; nitrogen, $0.32 \%$; and ash, $2.8 \%$. The theoretical higher heating value (HHV) of bagasse (46\% moisture, wet basis) was $9940 \mathrm{~kJ} / \mathrm{kg}$ (Lovero 2017). The entire set of equations and assumptions, as well as the adopted and calculated values, are fully described elsewhere (Lovero 2017). 

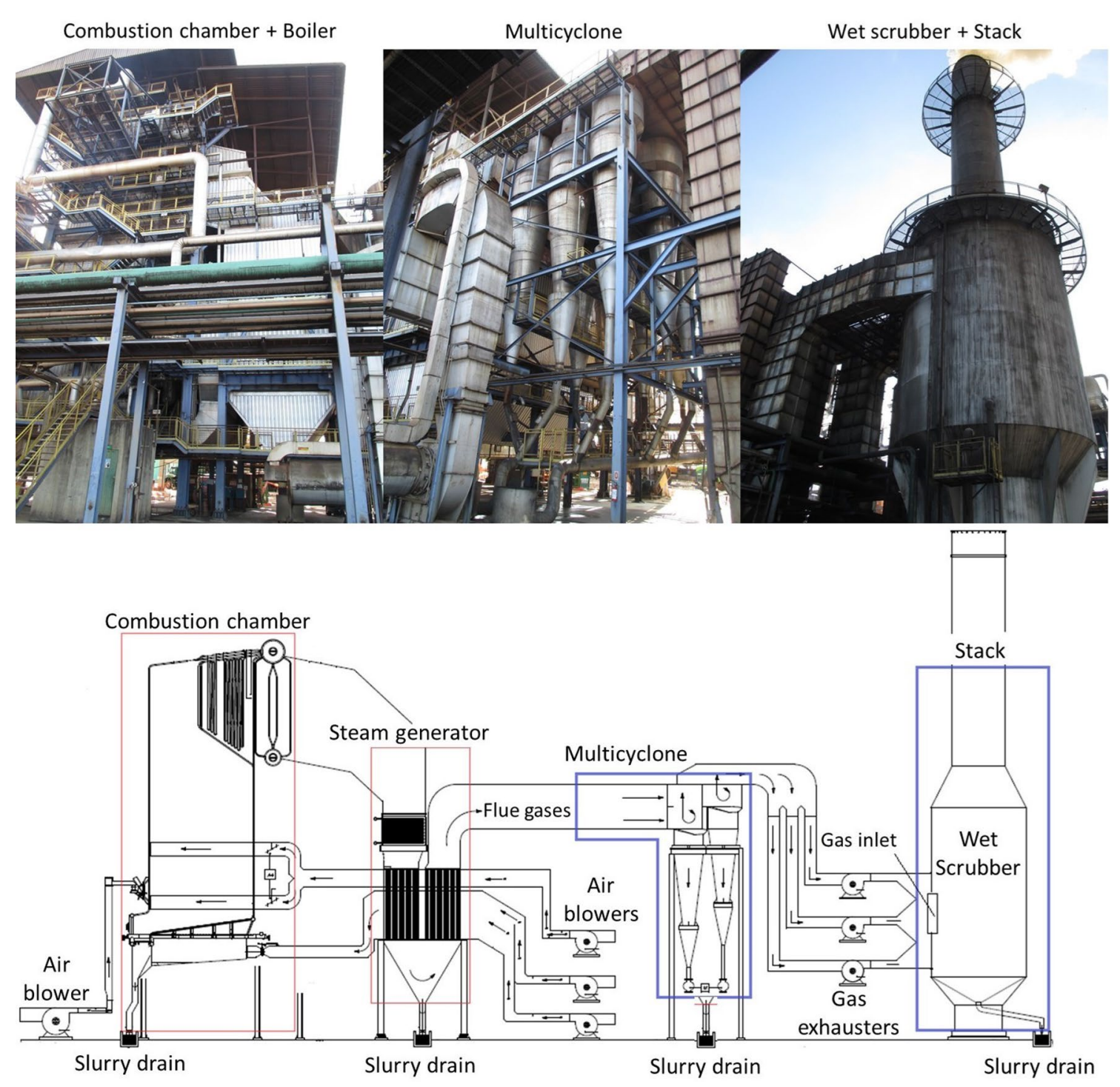

Fig. 3 Details of the steam generation process under study

The cyclone collector used in the plant was made up of 12 units connected in a parallel flow. Figure 5 shows the most important dimensions of each cyclone unit.

These cyclones have geometrical proportions similar to those of standard high-throughput Stairmand cyclones, as they are referred to in the literature (Coury et al. 2004). The efficiency $\left(\eta_{i}\right)$ by particle size $\left(d_{\mathrm{pi}}\right)$ for a multicyclone group can be calculated using the Iozia and Leith model (Coury et al. 2004).

The overall collection efficiency $\left(\eta_{\mathrm{o}}\right)$ of the multicyclone arrangement (i.e., the collected fraction of the total mass entering it) was calculated from the grade efficiency $\left(\eta_{i}\right)$ by:

$\eta_{\mathrm{o}}=\sum\left(w_{i} \eta_{i}\right)$ where $w_{i}$ is the mass fraction of particles with diameter $d_{\mathrm{pi}}$ at the inlet of the multicyclone.

The PM concentration at the multicyclone exit $\left(C_{\mathrm{o}}\right)$ was obtained as:

$C_{\mathrm{o}}=\frac{W_{i}\left(1-\eta_{\mathrm{o}}\right)}{Q}$

where $W_{i}$ is the total PM mass flow rate at the multicyclone inlet and $Q$ is the volumetric flow rate of the flue gases. To enable comparison with the Brazilian PM ELV $\left(200 \mathrm{mg} / \mathrm{Nm}^{3}\right)$ (CONAMA 2006, 2011), the exit concentration $\mathrm{C}_{\mathrm{o}}$ must be corrected for the normalized pressure $(101.325 \mathrm{kPa})$, temperature $(273 \mathrm{~K})$, and $\mathrm{O}_{2}$ concentration ( $8 \%$ on a dry basis). Based on the geometrical proportions of the cyclone and its operational conditions, the pressure 


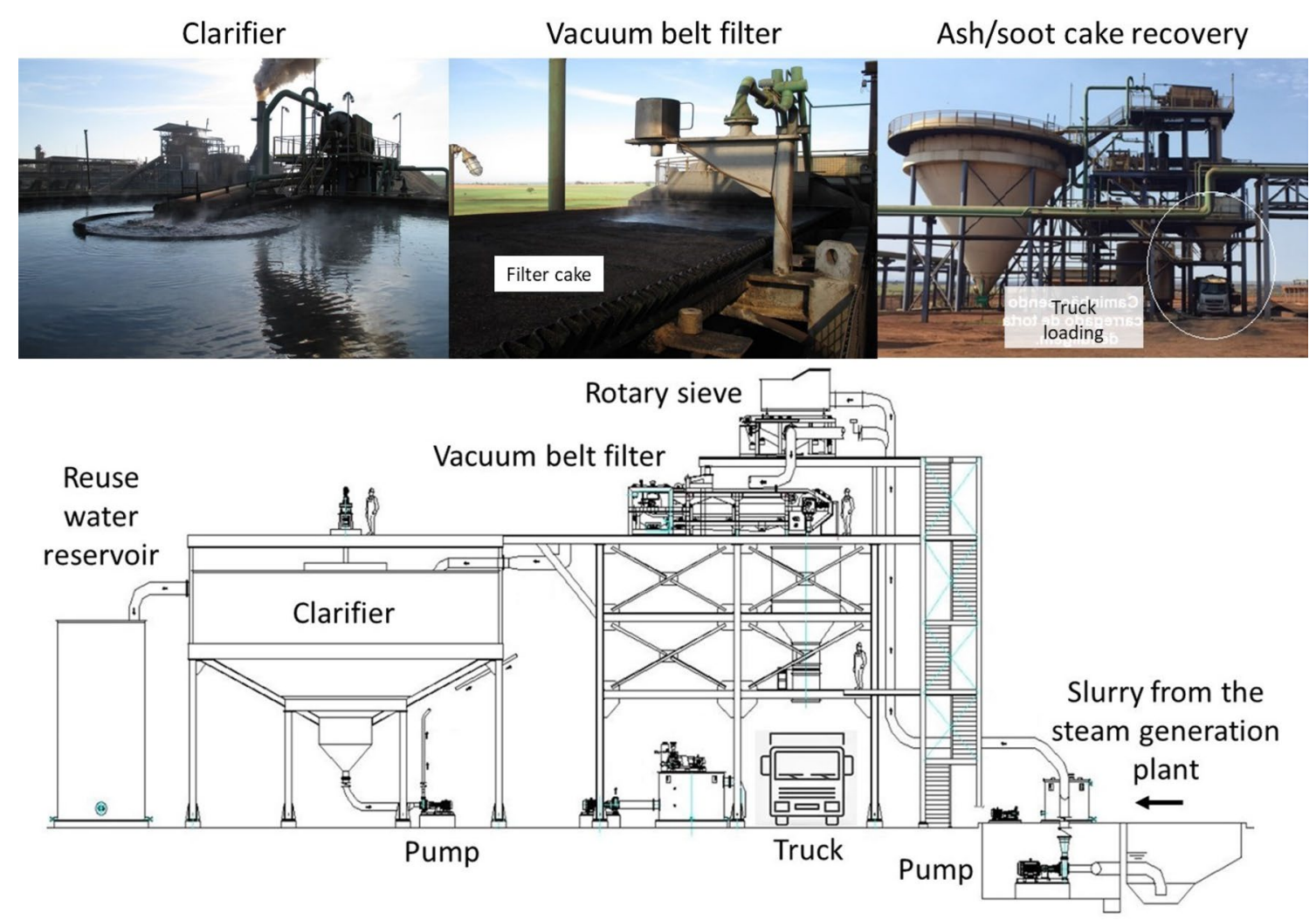

Fig. 4 Details of the wastewater treatment station coupled to the steam generation plant

Fig. 5 Geometrical proportions and main useful dimensions of a 12-unit multicyclone installed in the flue gas treatment unit

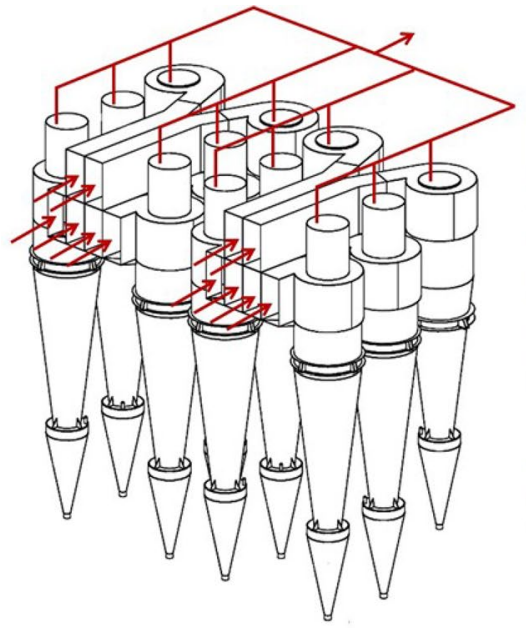

\begin{tabular}{llll}
\hline \multicolumn{2}{c}{$\begin{array}{c}\text { Dimensions of } \\
\text { each cyclone }\end{array}$} & \multicolumn{2}{c}{ Proportions } \\
\hline $\mathrm{D}_{\mathrm{c}}(\mathrm{m})$ & 2.101 & $\mathrm{D}_{\mathrm{c}} / \mathrm{D}_{\mathrm{c}}(\mathrm{m})$ & 1.000 \\
$\mathrm{a}(\mathrm{m})$ & 1.563 & $\mathrm{a} / \mathrm{D}_{\mathrm{c}}(\mathrm{m})$ & 0.744 \\
$\mathrm{~b}(\mathrm{~m})$ & 0.788 & $\mathrm{~b} / \mathrm{D}_{\mathrm{c}}(\mathrm{m})$ & 0.375 \\
$\mathrm{H}(\mathrm{m})$ & 8.403 & $\mathrm{H} / \mathrm{D}_{\mathrm{c}}(\mathrm{m})$ & 4.000 \\
$\mathrm{~h}(\mathrm{~m})$ & 3.151 & $\mathrm{~h} / \mathrm{D}_{\mathrm{c}}(\mathrm{m})$ & 1.500 \\
$\mathrm{D}(\mathrm{m})$ & 1.313 & $\mathrm{D}_{\mathrm{e}} / \mathrm{D}_{\mathrm{c}}(\mathrm{m})$ & 0.625 \\
$\mathrm{~B}(\mathrm{~m})$ & 0.840 & $\mathrm{~B} / \mathrm{D}_{\mathrm{c}}(\mathrm{m})$ & 0.400 \\
$\mathrm{~S}(\mathrm{~m})$ & 1.471 & $\mathrm{~S} / \mathrm{D}_{\mathrm{c}}(\mathrm{m})$ & 0.700 \\
\hline
\end{tabular}

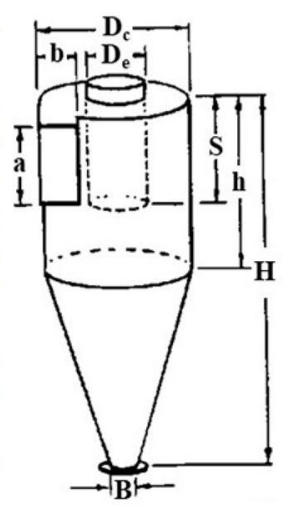

Arrangement of 12 cyclones

in parallel

drop through the parallel arrangement of cyclones was estimated using equations presented by Coury et al. (2004). The possibility of increasing the number of cyclone units working in parallel while keeping the geometrical proportions (Fig. 5) and inlet gas velocity of each cyclone constant was investigated. To maintain the same operational power input, the pressure drop in the multicyclone arrangement was also fixed at the theoretical value estimated for a 12-unit installation $(667 \mathrm{~Pa})$. The number of simulated units for the arrangement ranged from 12 (the actual device) to 350 . The PM size distributions at the inlet and outlet flows of each cleaning device (multicyclone and wet scrubber) were not 
experimentally evaluated in this work because Brazilian Resolutions 382/2006 and 436/2011 require the evaluation of only PM concentrations exhausted to the stack. Instead, two hypothetical size distributions were used in this work to represent the limit conditions (finest and coarsest) reported in the literature for PM emissions by sugarcane bagasse boilers (Teixeira et al. 2007). Figure 6 shows the cumulative size distribution (Fig. 6a) and the mass frequency (Fig. 6b) as a function of the particle size of the PM considered.

The capital expenditure (CAPEX) and operational and maintenance (O\&M) costs of the gas cleaning and wastewater treatment facilities were estimated to assess the economic impacts of the use of water in the wet scrubber (EPA 2002). As shown in Fig. 4, the WTS consists of several components, including a rotary sieve, sedimentation tank, vacuum belt filter, centrifugal pumps, pipelines, and a metallic structure. The purchase and operating costs of all pieces of equipment were calculated in US dollars (US\$) using costestimating methodologies for air pollution control devices (Turton et al. 2018), power plant performance (NETL 2011), and water treatment facilities (NETL 2011). The cost analysis methodology was comparable to that proposed by Das (2020). The maintenance costs for the wet scrubber and the WTS were set at $5 \%$ of their respective capital costs. The annual operating costs included the costs for all electrical devices (pumps, exhausters/fans, filters, etc.), as well as the costs of wastewater treatment for reuse and water losses (Lovero 2017). The plant is self-sufficient and sold its excess electric energy to the national grid in 2017 for US\$60 per MWh. This amount was set as the base cost for all electrical items in the 5760-h-per-year operation period. Additional information about the equations and assumptions used in the cost analysis can be found in the supplementary files and in the literature (Lovero 2017).

\section{Results and discussion}

\section{The mass balance of the process}

Figure 7 shows the overall mass balance of the process, and Table 1 lists all critical performance indicators for the plant,
Fig. 6 Coarsest and finest particle size distributions reported in the literature for PM emitted by bagasse boilers ( adapted from Rein, 2007)
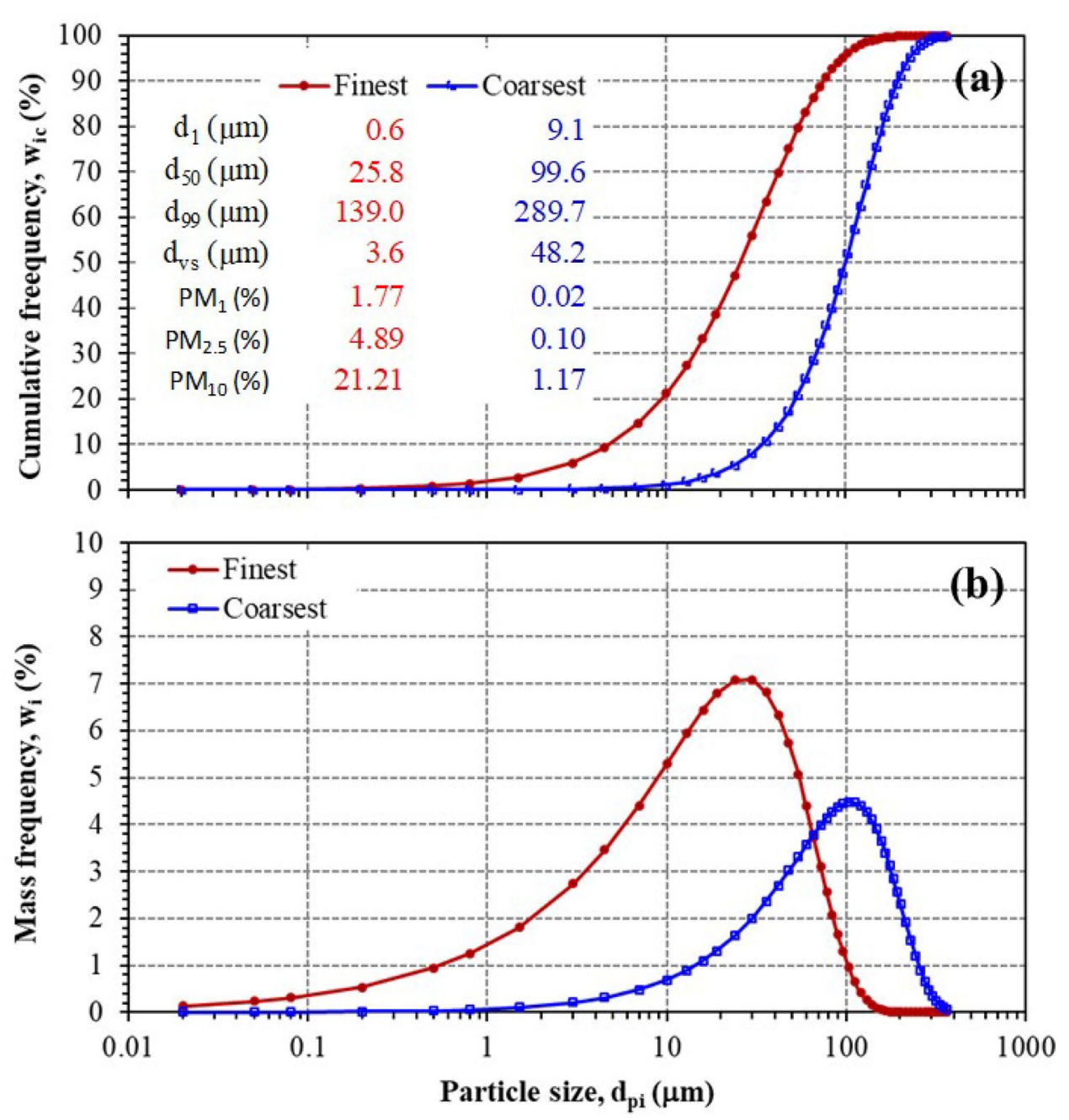


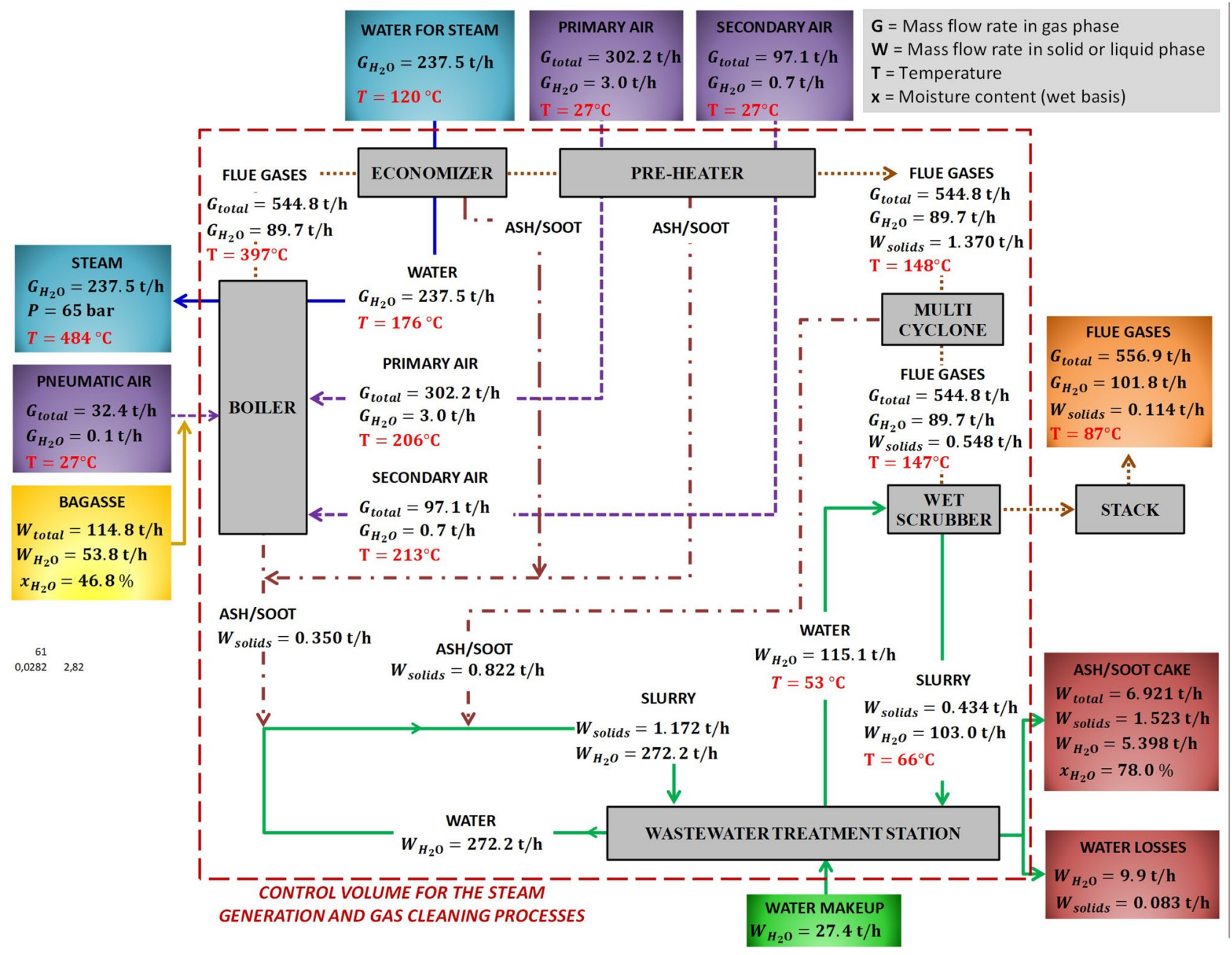

Fig. 7 Process flowsheet with the mass balance for steam generation, flue gas cleaning, and wastewater treatment

which burned $114.8 \mathrm{t} / \mathrm{h}$ of bagasse with $46.8 \%$ moisture (wet basis) on average and produced $237.5 \mathrm{t} / \mathrm{h}$ of steam at $484{ }^{\circ} \mathrm{C}$ and $65 \mathrm{bar}(6.5 \mathrm{MPa})$. The process produced $1.72 \mathrm{t} / \mathrm{h}$ of dry $\mathrm{PM}$, which corresponded to an average of $28.2 \mathrm{~kg}$ solids $/ \mathrm{t}$ dry burned bagasse. The boiler grate and heat exchangers retained $20 \%$ of this total, the multicyclone collected $48 \%$, the wet scrubber collected $25 \%$, and the remaining $7 \%$ was released to the atmosphere in the flue gases. The mass flow rate of flue gases was $544.8 \mathrm{t} / \mathrm{h}$ ( $16.5 \mathrm{wt} \%$ humidity), with a generation ratio of $4.75 \mathrm{t}$ gas/t bagasse. The emitted PM and NOx concentrations in the stack were monitored on a regular basis to ensure compliance with environmental regulations (CONAMA 2011).

The average water ratio used to clean the flue gases was $0.813 \mathrm{t} / \mathrm{t}$ cane crushed (3.4 t water/t burned bagasse or $1.6 \mathrm{t}$ water/t steam produced), which is consistent with literature values for sugarcane processing in Brazil (CGEE 2012). Nonetheless, these indicators do not imply rational use of water and could be reduced further by changes in the conveyor and treatment of collected ash in the WTS. The concentration of PM carried in the flue gases to the cleaning system, on the other hand, was higher than the average emission ratio reported in the literature $(7.8 \mathrm{~kg} / \mathrm{t})$ (Teixeira et al. 2007). Water losses were $27.4 \mathrm{t} / \mathrm{h}$, with $44 \%$ evaporated in the wet scrubber, $20 \%$ in the moisture of the char-ash cake, and 36\% with periodic WTS drainage. In the 2016-2017 season, the char/ash cake produced was $6.92 \mathrm{t} / \mathrm{h}$ with $78 \%$ moisture (wet basis), for a total of 39,900 $t$ and requiring nearly 4,000 trucks to dispose of the cake in the composting yard.

Notably, the water treatment station distributed $387.3 \mathrm{t} / \mathrm{h}$ of water, $70 \%$ of which was used to remove PM from the boiler, heat exchangers, and multicyclone, and only $30 \%$ was used to operate the wet scrubber. Although the ash collected in the boiler (ash tray) and the multicyclone was dry, it was discharged directly into a water channel that pumped the formed slurry to the WTS. The water stream used for this purpose accounted for the majority of the water recirculated 
Table 1 Key performance parameters of the steam generation plant and the flue gas cleaning facilities

\begin{tabular}{|c|c|c|c|}
\hline \multirow{2}{*}{ Parameter } & \multicolumn{3}{|c|}{ Ratio } \\
\hline & $\left(t / t_{\text {cane crushed }}\right)^{(1)}$ & $\left(t / t_{\text {bagasse burned }}\right)^{(2)}$ & $\left(t / t_{\text {steam produced }}\right)^{(3)}$ \\
\hline Sugarcane crushed & 1.000 & 4.147 & 2.005 \\
\hline Bagasse burned (moisture $46.8 \% \mathrm{wb}$ ) & 0.241 & 1.000 & 0.483 \\
\hline Steam produced $\left(484^{\circ} \mathrm{C} / 6.5 \mathrm{MPa}\right)$ & 0.499 & 2.069 & 1.000 \\
\hline Combustion air (total) & 0.907 & 3.760 & 1.818 \\
\hline Flue gas generated & 1.144 & 4.746 & 2.294 \\
\hline PM generated ${ }^{(4)}$ & 3.613 & 14.983 & 7.242 \\
\hline PM conveyed in the flue gases ${ }^{(4)}$ & 2.890 & 11.986 & 5.794 \\
\hline Flue gas emitted (total) & 1.170 & 4.851 & 2.345 \\
\hline Flue gas emitted (dry) & 0.956 & 3.964 & 1.916 \\
\hline Flue gas emitted (vapor) & 0.214 & 0.887 & 0.429 \\
\hline PM collected ${ }^{(4)}$ & 2.651 & 10.993 & 5.314 \\
\hline PM emitted ${ }^{(4)}$ & 0.239 & 0.993 & 0.480 \\
\hline Water use (total) & 0.813 & 3.374 & 1.631 \\
\hline Water use (scrubbing) & 0.242 & 1.003 & 0.485 \\
\hline Ash cake produced (moisture $78 \% \mathrm{wb}$ ) & 0.015 & 0.060 & 0.029 \\
\hline Water loss (total) & 0.058 & 0.239 & 0.115 \\
\hline Water loss (evaporation in the scrubber) & 0.025 & 0.105 & 0.051 \\
\hline Water loss (moisture in the ash cake) & 0.011 & 0.047 & 0.023 \\
\hline \multicolumn{4}{|c|}{ (1) Average sugarcane crushed in the season 2016-2017 (240 days $x 24$ h): 476.1 t/h } \\
\hline \multicolumn{4}{|c|}{ (2) Average bagasse burned in the season 2016-2017: 114.8 t/h (moisture 46.8\% wb) } \\
\hline \multicolumn{4}{|c|}{ (3) Average steam produced in the season 2016-2017: $237.5 \mathrm{t} / \mathrm{h}\left(484^{\circ} \mathrm{C} / 6.5 \mathrm{MPa}\right)$} \\
\hline (4) Given in $\mathrm{kg} / \mathrm{t}$ & & & \\
\hline
\end{tabular}

in the system (70\%). This is an environmentally harmful procedure used in many ethanol plants in Brazil. In fact, the previously dry-collected material is dispersed in water for subsequent separation in vacuum filters, resulting in an ash cake with a high moisture level and thus water loss. The belief in the industry is that the wet transport of collected ash is safer, faster and less expensive because only pumps are used. Most industries are concerned that the handling and conveyance of dry hot ash may cause fires because of its easier dispersion in an industrial yard. However, such industries do not account for the costs associated with a larger WTS and greater recirculated water flows, nor do they plan to invest in optimized handling of dry ash to reduce dispersion and contamination.

\section{The energy (heat) balance of the process}

Figure 8 shows that the theoretical thermal power generated from bagasse combustion was $259 \mathrm{MW}$, with equivalent steam generation of $173.6 \mathrm{MW}$. The thermal efficiencies of the combustion chamber and of the steam generation were $67 \%$ and $73 \%$, respectively, below the nominal supplier's value of $82.8 \%$. The combustion efficiency based on the concentrations of $\mathrm{CO}$ and $\mathrm{CO}_{2}$ in the flue gas stream was not evaluated in this work because Brazilian Resolutions 382/2006 and 436/2011 require only the periodic measurement of carbon monoxide (CO) for boilers with a nominal power less than $10 \mathrm{MW}$ (CONAMA 2006, 2011). The dispersed thermal power was approximately 40.4 MW in the combustion chamber and approximately 8.4 MW in the economizer and air preheater units, accounting for nearly $18 \%$ of the total available heat; the multicyclone lost only $0.2 \mathrm{MW}$. The wet scrubber, on the other hand, resulted in a temperature drop of $60^{\circ} \mathrm{C}$ in the flue gases, as well as the evaporation of $12.1 \mathrm{t} / \mathrm{h}$ (10.5\%) of scrubbing water and a heat reduction of $10.2 \mathrm{MW}$. This energy loss could be minimized by combining dry cleaning technology with a heat exchanger. The total pressure drop through the multicyclone and wet scrubber was estimated to be $2.8 \mathrm{kPa}$. The annual electricity consumption by the exhausters associated with these two devices for a flue gas 
Fig. 8 Main heat flows in the bagasse boiler and in the flue gas cleaning system

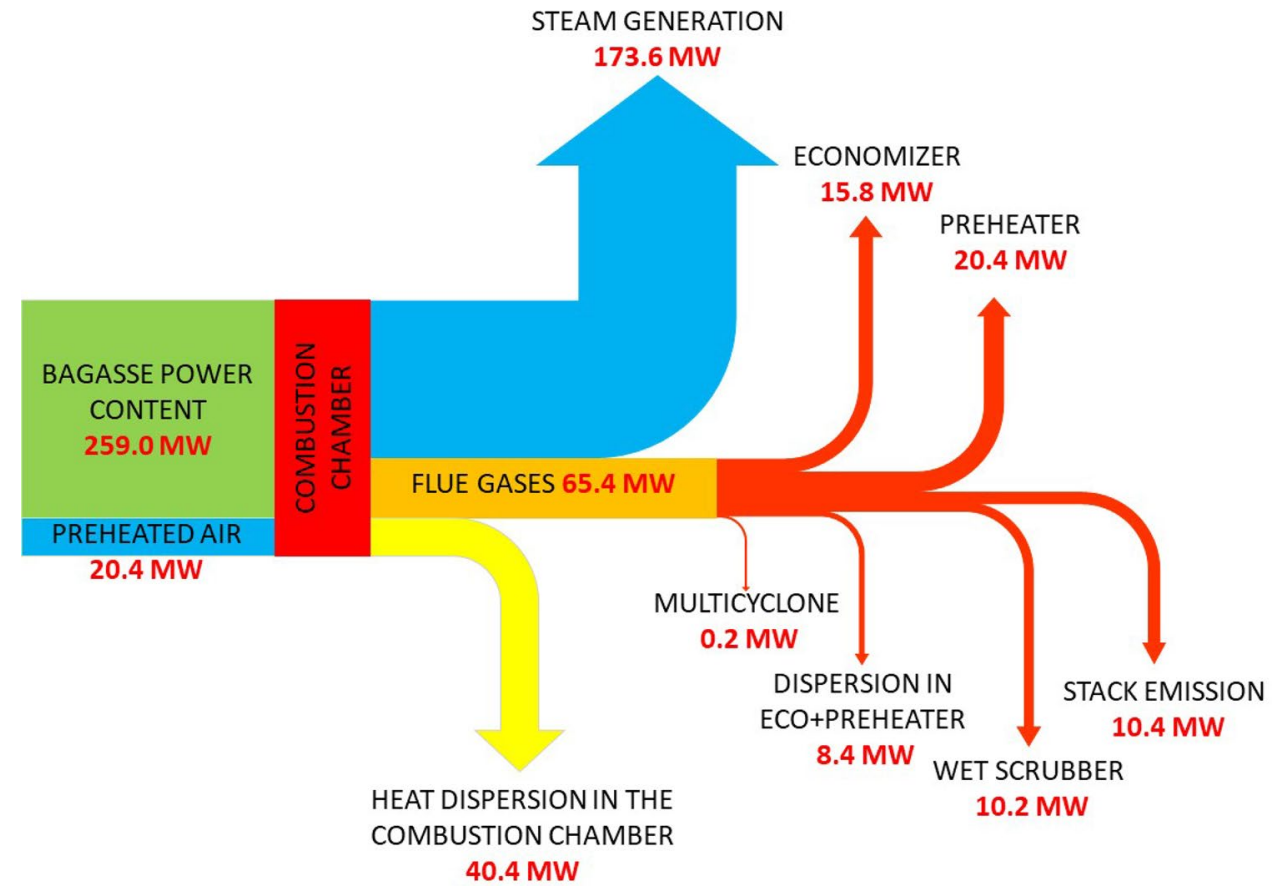

flow of $151.3 \mathrm{~kg} / \mathrm{s}\left(202.9 \mathrm{Am}^{3} / \mathrm{s}\right.$ at $\left.148{ }^{\circ} \mathrm{C} / 94.6 \mathrm{kPa}\right)$ was 4,650 MWh (70\% fan efficiency).

\section{Cost analysis}

Figure 9 shows the itemized capital and operational costs for the cleaning process. The costs for the PM collection devices accounted for only $38 \%$ of the total CAPEX. The WTS, on the other hand, accounted for $62 \%$ of the CAPEX (US $\$ 1,475,600)$ and $24 \%$ of the annual operation costs (US\$167,000/year), not including maintenance. The annualized O\&M costs reached US $\$ 96 /$ ty (US dollars per ton of PM collected per year), which is comparable to the costs of a combination of a multicyclone (US\$55/ty) and a Venturi scrubber (US\$44/ty) given by Das (2020) for a cleaning system with a similar gas flow capacity $\left(92.1 \mathrm{Nm}^{3} / \mathrm{s}\right.$ dry basis).

The disposal of collected solids in the field could result in significant savings if dry gas cleaning technologies are used. As previously stated, the wet cake produced by an WTS can contain up to $80 \%$ moisture. As a result, the solid fraction actually transported by trucks from the WTS to a landfill or composting yard may be as low as $20 \%$. In the current study, $8770 \mathrm{t}$ of dry PM was collected during the 2016-2017 season, resulting in 39,865 t of cake with 78\% moisture. During the period, 3987 trips (17 trips per day) by $10 \mathrm{t}$ trucks were required to transport the cake an average travel distance of $30 \mathrm{~km}$ to a composting yard. Despite the lower bulk density of dry solids $\left(960 \mathrm{~kg} / \mathrm{m}^{3}\right)$ than of moist cake $\left(1151 \mathrm{~kg} / \mathrm{m}^{3}\right)$, the water economy would be $31.1 \mathrm{Mt}$, and the savings from the reduced fuel consumption (excluding truck and equipment maintenance) with dry solids disposal would be US\$33,489 per season, as shown in Table 2.

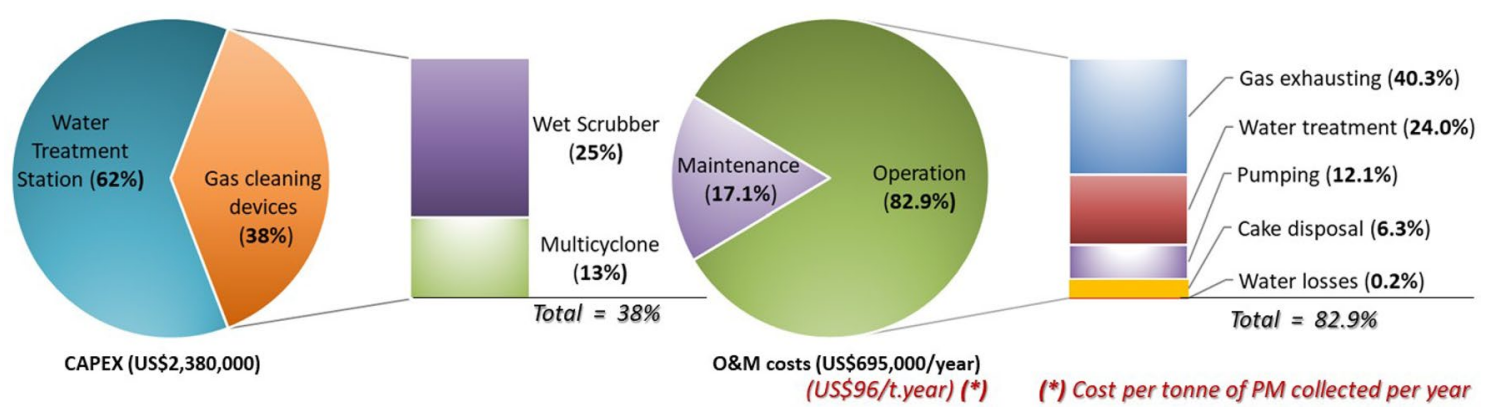

Fig. 9 Costs associated with the acquisition, operation, and maintenance of the flue gas cleaning and wastewater treatment facilities 
Table 2 Costs associated with the wet and dry disposal of char/ash cake from the bagasse boiler in the current study

$\begin{array}{rrr} & \\ & & \text { From wet } \\ \text { Scrubber + wst }\end{array}$

${ }^{*}$ ) Considering a collection efficiency of $100 \%$

\section{Strategies to minimize water use in the gas cleaning process}

As Fig. 10 shows, there are at least seven major constructive/ operational strategies reported in the literature to provide both compliance with PM emission limits and water reduction in bagasse-fired boilers.

The concept of the best available control technology (BACT) for PM removal could also be applied (Das 2020). The efficiency of fabric filters (FFs) at removing PM is comparable to or greater than the efficiency of a combination of a multicyclone (MC) and a Venturi scrubber (VS). This author also demonstrates that, depending on plant capacity, the annualized costs of an FF would be 4 to $32 \%$ lower than those of an MC + VS combination. Furthermore, the operating costs of scrubbers with freshwater, wastewater treatment, and wet cake disposal have not been computed using conventional cost methodologies, which could increase the difference between dry and wet technologies. The development of more efficient (multi)cyclones is another effective strategy, especially if it can reduce or eliminate the need for a secondstage wet collector (Boshoff and Yeo 1999). In fact, cyclones were among the first dry mechanical collectors used in South Africa (Allan and Fitzgerald 1972), Australia (Flood and Frew 1974), and the United States (EPA 1975) to control PM emissions from bagasse-fired boilers. The coupling of cyclones with wet scrubbers was a quick and logical choice for most Brazilian sugarcane industries to meet the more stringent emission limits, primarily favored by the availability and low cost of freshwater for scrubbing and the lack of more stringent wastewater management regulations. As a result, optimization of multicyclones was no longer required or encouraged.

\section{Optimization of multicyclones}

Determining the parameters representative of both the gas and PM phases emitted from bagasse-fired boilers may be 


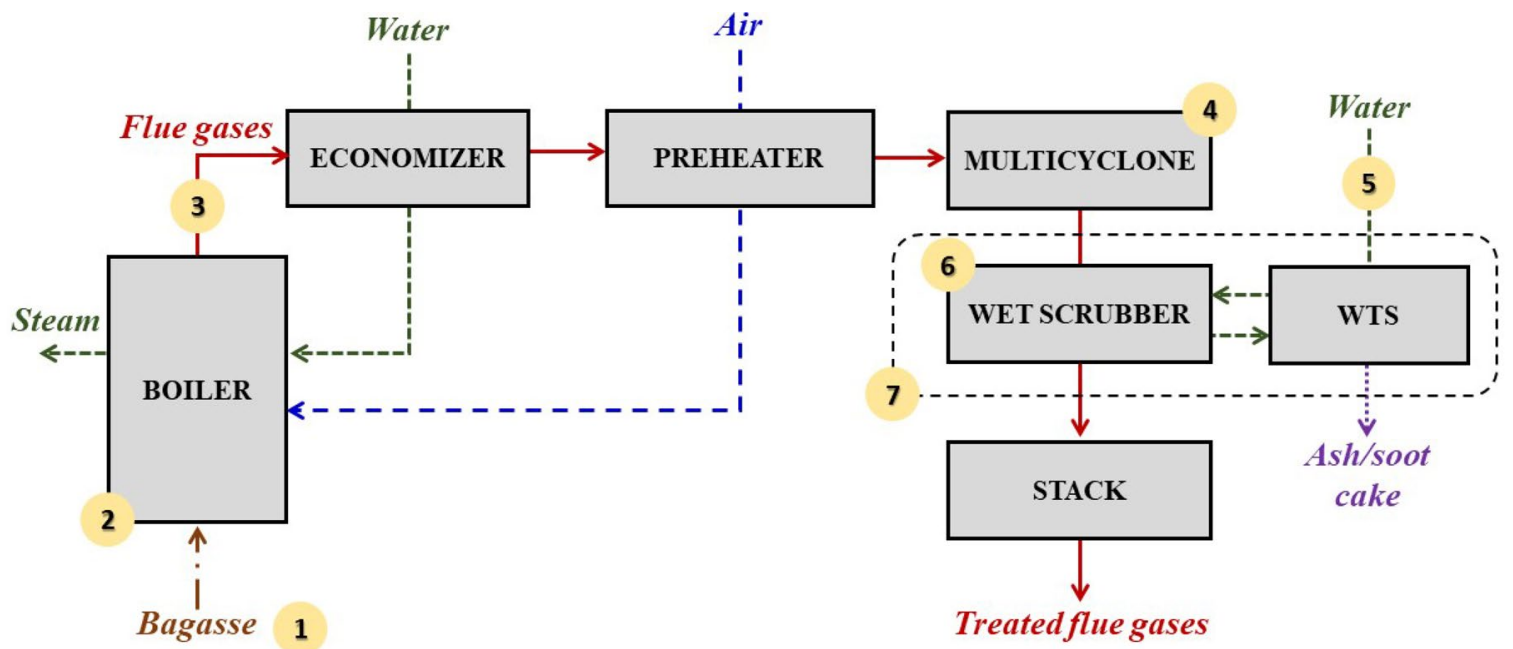

1 The bagasse moisture content is $48-52 \%$. Bagasse drying to achieve moisture $<30 \%$ is feasible using the waste heat energy present in the flue gases. An increase up to $60 \%$ in the calorific value of bagasse would be possible, with a proportional decrease in the specific flue gas generation $\left(t_{\mathrm{FG}} / \mathrm{t}_{\text {bagasse }}\right.$ ) and size of cleaning devices (Sosa-Arnao and Nebra, 2009).

2 The use of high-pressure boilers with high-efficiency turbines reduces the specific bagasse consumption $\left(\mathrm{t}_{\text {bagasse }} / \mathrm{t}_{\text {steam }}\right)$, the specific flue gas generation $\left(\mathrm{t}_{\mathrm{FG}} / \mathrm{t}_{\text {bagasse }}\right)$ and the concentration of soot and unburned materials in the gas stream. This reduces the target efficiency of downstream collectors and/or the water use in wet scrubbers (Khoodaruth, 2014).

3 Inertial separators can be optimized to remove a higher fraction of sand and coarse particles conveyed in the flue gas stream. This reduces the target efficiency of downstream collectors and/or the water use in wet collectors (Rosendahl, 2013).

4 Multicyclones could be resized for high-efficiency collection of small particles (Benthum, 2007). This reduces the target efficiency of downstream collectors and/or the water use in wet scrubbers (Rein, 2007).

5 Treated vinasse can replace fresh water as the scrubbing liquid. The slurry containing both ash cake and effluent vinasse can be disposed of in the soil for fertigation without further treatment or recirculation (Innocentini et al.,

6 2011).

Venturi or impingement scrubbers can replace spray towers with higher collection efficiency and lower water

7 consumption(Mann, 2017).

Heat-resistant bag filters, ceramic filters (Heidenreich, 2013), granular filters (Xiao et al., 2013) and electrostatic precipitators (Inkson et al., 2010) can replace wet scrubbers with higher collection efficiency.

Fig. 10 Main strategies to comply with PM emission limits and minimize the water consumption in wet scrubbers coupled to bagasse-fired boilers

the most difficult aspect of multicyclones optimization. Based on an elemental analysis of the bagasse, the combustion stoichiometry, the air-to-bagasse ratio, and the temperature and pressure of a flue gas stream, the mass flow rate, main chemical composition $\left(\mathrm{CO}_{2}, \mathrm{O}_{2}, \mathrm{~N}_{2}\right.$, and $\left.\mathrm{H}_{2} \mathrm{O}\right)$, and physical properties (density and viscosity) of the gas phase can be theoretically predicted. For most vertical water tube boilers, temperature and pressure are currently well established: $T=150-170{ }^{\circ} \mathrm{C}$ (after heat recovery systems) and $P=P_{\mathrm{atm}}=90-101 \mathrm{kPa}$. The particulate phase contained in flue gases, on the other hand, contains fractions of inorganic material, soot, and char (carbon residues), as well as unburned bagasse particles with a wide range of compositions, concentrations, and particle size distributions. According to the literature, the mineral ash content of dry bagasse ranges from 2 to $10 \%$ by weight (Rein 2007). Organic and inorganic particle densities range from 300 to $600 \mathrm{~kg} / \mathrm{m}^{3}$ and 1900 to $2800 \mathrm{~kg} / \mathrm{m}^{3}$, respectively. The actual values are determined by the fly ash composition, but the range $1600-2000 \mathrm{~kg} / \mathrm{m}^{3}$ has been reported most frequently in the literature on gas cleaning (Rein 2007). The concentration of PM in the flue gases released by the furnace is also highly dependent on the mineral content and the carbon fraction left over after bagasse combustion (Lora and Hervas 1999). Values ranging from 1000 to $30,000 \mathrm{mg} / \mathrm{Nm}^{3}$ have been reported (Moor 2007; Rein 2007), while the value 
found in this study was $4133 \mathrm{mg} / \mathrm{Nm}^{3}$. Because of the wide variability in PM concentration, the collection efficiency required to meet the legal standard limits is also variable, influencing the selection of the cleaning technology with the best benefit-cost ratio. The overall collection efficiency $\left(\eta_{o, R}\right)$ required to meet a given PM stack ELV is given as:

$\eta_{\mathrm{o}, \mathrm{R}}=\frac{\left(C_{i}-\mathrm{ELV}\right)}{C_{i}} 100 \%$

where $C_{i}$ is the concentration of PM in the flue gases entering the cleaning device and ELV is the legal maximum stack emission allowed for boiler operation, with both corresponding to standard conditions (for example, $\mathrm{mg} / \mathrm{Nm}^{3}$ at $1 \mathrm{~atm}$ and $273 \mathrm{~K}$, dry basis). Most countries set ELV levels ranging from 120 to $350 \mathrm{mg} / \mathrm{Nm}^{3}$. In Brazil, CONAMA Resolutions $382 / 2006$ and 436/2011 impose an ELV of 200 to $280 \mathrm{mg} /$ $\mathrm{Nm}^{3}$ on a dry basis with $8 \% \mathrm{O}_{2}$ for bagasse combustion in sources installed after 2007 (CONAMA 2006, 2011). As a result, depending on the actual value of $C_{i}$ (1000 to $\left.30,000 \mathrm{mg} / \mathrm{Nm}^{3}\right)$ and the ELV ranges, the overall efficiencies required for boilers range from 65 to $99.6 \%$ in most countries and from 72 to $99.3 \%$ in Brazil, as illustrated in Fig. 11. The most stringent ELV for biomass boilers is found in China $\left(80 \mathrm{mg} / \mathrm{Nm}^{3}\right.$ ) (Zhang et al. 2020), where the PM collector efficiency must be between 92 and $99.7 \%$. In the current study, $C_{i}=4133 \mathrm{mg} / \mathrm{Nm}^{3}$, and $\mathrm{ELV}=200 \mathrm{mg} / \mathrm{Nm}^{3}$, resulting in an overall PM collection efficiency of $\eta_{\mathrm{o}, \mathrm{R}}=95.2 \%$.

The required overall collection efficiency (95.2\%) is not a constraint for most available dry cleaning devices (cyclones, barrier filters, electrostatic precipitators, and so on), but the high variability in the PM size distribution in flue gases from bagasse boilers may limit the viable options. Table 3 shows
Table 3 Main parameters of the flue gas stream emitted by a bagasse boiler for simulation of the performance of PM cleaning devices

\begin{tabular}{|c|c|c|}
\hline Flue gases & Wet basis & Dry basis \\
\hline Temperature $\left({ }^{\circ} \mathrm{C}\right)$ & 14.8 & \\
\hline Absolute pressure $(\mathrm{kPa})$ & 94.6 & \\
\hline Molar mass (g/mol) & 27.2 & 30.8 \\
\hline Gas density $\left(\mathrm{kg} / \mathrm{m}^{3}\right)$ & 0.744 & 0.831 \\
\hline Gas viscosity (Pa s) & $2.41 \times 10^{-5}$ & \\
\hline Mass flow rate $(\mathrm{kg} / \mathrm{h})$ & 731,887 & 547.559 \\
\hline Volumetric flow rate, actual $\left(\mathrm{m}^{3} / \mathrm{h}\right)$ & 123.1 & 92.1 \\
\hline \multicolumn{3}{|l|}{ Gas composition $(\% \mathrm{~mol} / \mathrm{mol})$} \\
\hline $\mathrm{N}_{2}$ & 59.2 & 79.2 \\
\hline $\mathrm{CO}_{2}$ & 12.0 & 16.0 \\
\hline $\mathrm{O}_{2}$ & 3.6 & 4.9 \\
\hline $\mathrm{H}_{2} \mathrm{O}$ & 25.2 & - \\
\hline $\mathrm{SO}_{2}^{\mathrm{b}}$ & 46.8 & 62.3 \\
\hline \multicolumn{3}{|l|}{ Particulate matter (PM) } \\
\hline Particle density $\left(\mathrm{kg} / \mathrm{m}^{3}\right)$ & 1600 & \\
\hline Mass flow rate $(\mathrm{kg} / \mathrm{h})^{\mathrm{b}}$ & 1372 & \\
\hline Concentration, actual $\left(\mathrm{mg} / \mathrm{m}^{3}\right)$ & 1872 & 2502 \\
\hline Concentration, STP $\left(\mathrm{mg} / \mathrm{Nm}^{3}\right)$ & 3092 & 4133 \\
\hline
\end{tabular}

${ }^{\mathrm{a}}$ In ppm, v

${ }^{\mathrm{b}}$ After the air preheater

the main flue gas stream parameters, and Fig. 12 shows the results of simulations of a multicyclone collector with a variable number of units.

One advantage of combining cyclones in a parallel flow is that the dimensions of each unit are proportionally reduced as $N_{\mathrm{c}}$ increases, resulting in a nearly constant space occupied by the multicyclone. On the other hand,
Fig. 11 Required collection efficiency for bagasse boilers based on the inlet PM concentration and emission limits imposed in Brazil, China, and most countries

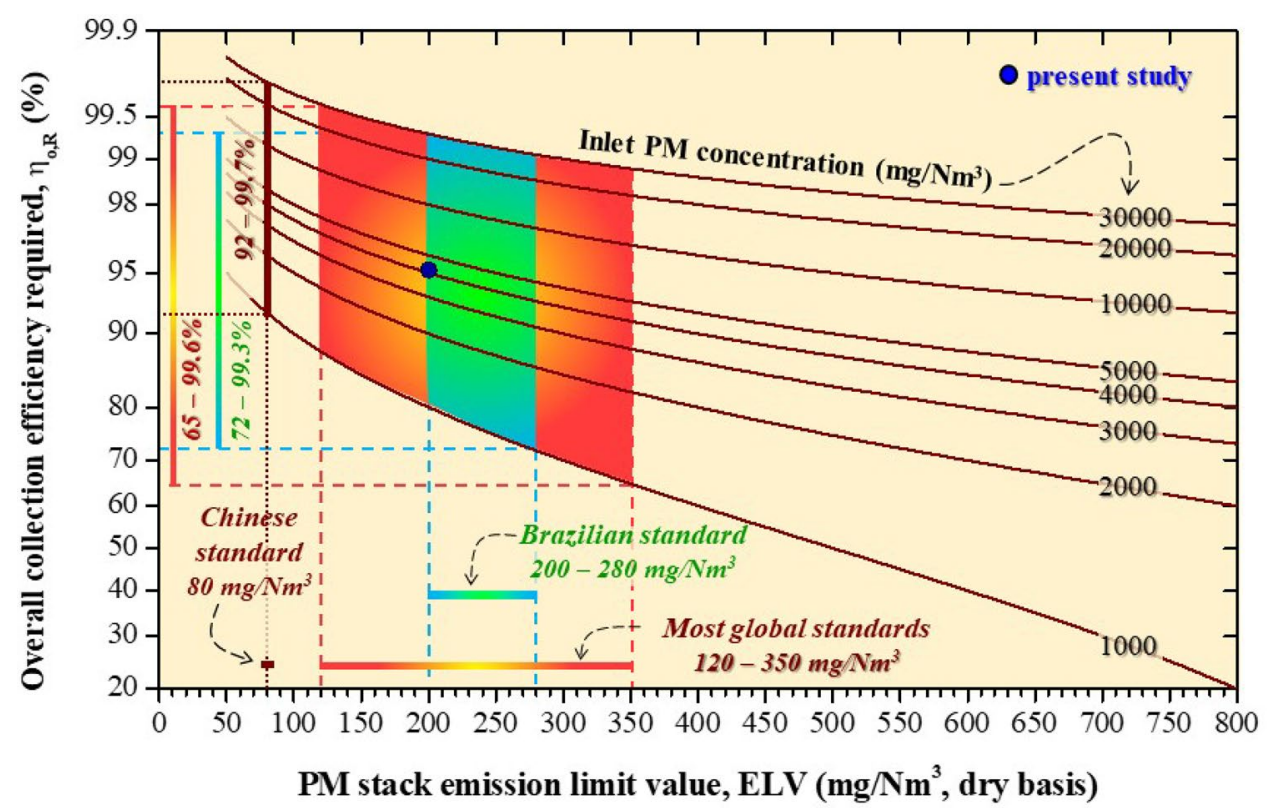


Fig. 12 Simulated performance parameters of multicyclones with an increasing number of parallel units: a overall collection efficiency; b normalized exit PM concentration; $\mathbf{c}$ complementary efficiency required to meet an ELV of $200 \mathrm{mg} / \mathrm{Nm}^{3}$

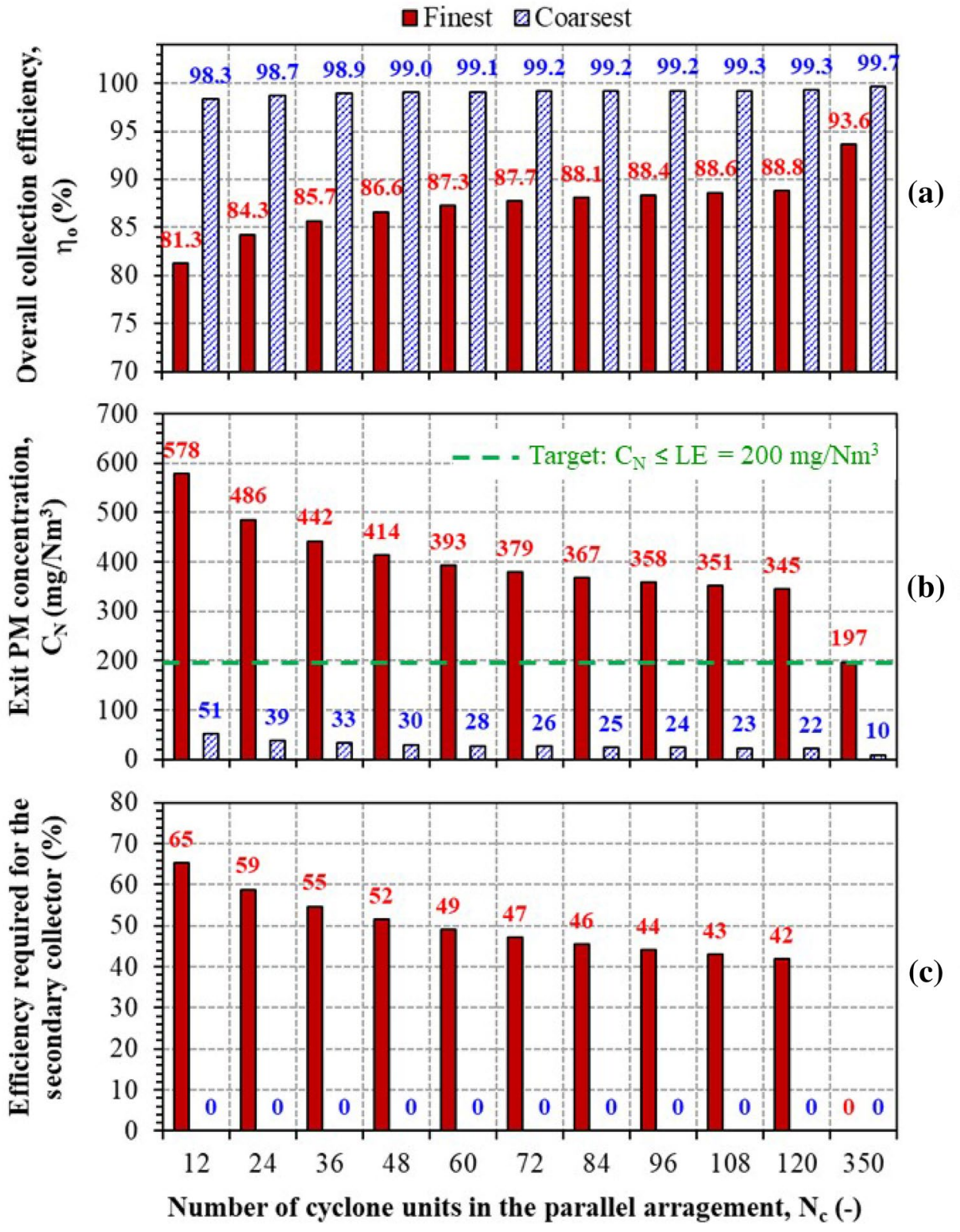

an increase in $N_{\mathrm{c}}$ improves the cyclone's overall efficiency $\left(\eta_{\mathrm{o}}\right)$. Figure 12 shows that, depending on the particle size distribution and the number of units $\mathrm{N}_{c}$, a multicyclone can be the only cleaning technique required to control $\mathrm{PM}$ emissions within the standard limit for a process. The collection efficiency for the coarsest size distribution, extracted from Rein (2007), can reach 99.3\% (Fig. 12a), and the normalized emission concentration $\left(C_{\mathrm{N}}\right)$ can be as low as $22 \mathrm{mg} / \mathrm{Nm}^{3}$ (Fig. 12b). On the other hand, for the finest dust size distribution, extracted from Lora and Hervas (1999), an increase in $N_{\mathrm{c}}$ with a sufficient reduction in $C_{\mathrm{N}}$ (from 578 to $197 \mathrm{mg} / \mathrm{Nm}^{3}$ ) to meet an ELV of $200 \mathrm{mg}$ / $\mathrm{Nm}^{3}$ results in a gain in efficiency (from 81.3 to $93.6 \%$ ).
Improvements in multicyclone performance can reduce the water demand in wet scrubbers by lowering the required complementary collection efficiency to meet the ELV. In Fig. 12c, the overall efficiency $\left(\eta_{\mathrm{o}}\right)$ required for the wet scrubber to meet the ELV should be reduced from $65 \%$ (actual device) to 0\% (350-unit multicyclone), which can theoretically be accomplished without much recirculating water and with lower water treatment costs. Another advantage of multicyclone optimization is the increased dry disposal of collected solids, which reduces fuel costs and the number of trips to the composting yard. 


\section{Replacement of wet scrubbers with other dry cleaning technologies}

Ceramic filters and electrostatic precipitators are the two main dry cleaning technologies that can easily achieve the required ELV for bagasse boilers, as shown in Fig. 9. Ceramic filters emit as little as $2 \mathrm{mg} / \mathrm{Nm}^{3}$ of $\mathrm{PM}$ and are thermally stable at temperatures above $800{ }^{\circ} \mathrm{C}$. There is no need to cool the flue gases, and no thermal heat energy is wasted. The use of hot gas filtration for fly ash removal instead of wet scrubbing increases the efficiency of coal gasification by approximately $3 \%$ (Heidenreich 2013). Ceramic filters are already in use in advanced power generation systems, oil refineries, incinerator, metal refining, and metal recycling, where the demand for gas cleaning is driven by increased process efficiency, process intensification, product quality, and environmental legislation (Heidenreich 2013). For bagasse boilers, the exhaust gas temperature after the heat exchangers typically drops to $160-190^{\circ} \mathrm{C}$, and a variety of conventional flexible filtering media (glass fiber, polyphenylene sulfide, polyamides, PTFE, and so on) can be used. In this case, the main disadvantage is the large filtering area required for operation. Face velocities of less than $2 \mathrm{~cm} / \mathrm{s}$ are common for bag and ceramic filters. Because of the high prices of the filtering elements, the flow rate given in Table 3 $\left(731,887 \mathrm{~m}^{3} / \mathrm{h}\right.$ at $\left.148{ }^{\circ} \mathrm{C}\right)$ implies a total area of $10,165 \mathrm{~m}^{2}$, which may jeopardize the viability of this technology. The possibility of soot cake ignition on the filter surface has also been mentioned as a disadvantage of using barrier filters in conjunction with bagasse boilers (Rein 2007). However, the cost savings from eliminating water from the cleaning process should be factored into an updated filter viability analysis (Lovero 2017). Electrostatic precipitators (ESPs) are another leading technology for controlling fine PM conveyed in hot flue gases. ESPs can operate with high efficiency (up to $99.5 \%$ ) at temperatures above $500{ }^{\circ} \mathrm{C}$ and with low pressure drops (100-250 Pa). ESPs are used in the cement and paper industries to control PM emissions from rotary kilns and recovery boilers, respectively. The main disadvantage of using ESPs in conjunction with bagasse boilers is the large size of the units. The high variability in particle size distribution and resistivity conveyed by flue gases causes fluctuations in an ESP, compromising its collection performance (Jaworek et al. 2011).

\section{Final remarks on process optimization}

According to the discussion in the preceding subsections, the operation of wet scrubbers coupled to bagasse boilers to control PM emissions is currently nonoptimized at many sugarcane production sites. As a result, water consumption increased, as did the costs of acquiring, operating, and maintaining the WTS. The main problems with the gas cleaning process, as well as suggestions for optimization, based on the observations and simulations performed in this work are listed in Table 4.

\section{Conclusions}

Wet scrubbers have been widely used in sugarcane industries around the world to control particulate emissions from bagasse-fired boilers. In the past, the choice was justified by the acceptable PM collection efficiency of wet scrubbers, the availability of water resources, and the fact that the acquisition costs were lower than those for other cleaning

Table 4 Summary of the problems exposed in the current study and recommendations for improving flue gas cleaning technology in the sugarcane industry

\begin{tabular}{lc}
\hline Problem & Proposed optimization \\
\hline $\begin{array}{l}\text { Transport of dry ash collected in the boiler (ash tray) and the multicy- } \\
\text { clone via water recirculation (hydraulic transport), increasing the size } \\
\text { and demand of the WTS }\end{array}$ & $\begin{array}{c}\text { Removal and disposal of collected dry ash in precollectors without } \\
\text { dispersion in water, as well as the use of a WTS }\end{array}$ \\
$\begin{array}{l}\text { Low efficiency of precollectors (multicyclone) } \\
\text { Improve the multicyclone efficiency through optimized design and siz- } \\
\text { ing to reduce wet cake accumulation in the WTS } \\
\text { Rnnecessarily high flow rate of recirculated water in the WTS } \\
\text { reduce the liquid/gas ratio and the water requirement for high collec- } \\
\text { tion efficiency } \\
\text { The use of high-efficiency dry collectors, such as ceramic filters, in } \\
\text { place of wet scrubbers to control emissions from hot flue gases }\end{array}$ \\
$\begin{array}{l}\text { Wet cake produced in vacuum filters with a high moisture content (up } \\
\text { to } 78 \% \text { wb), increasing water loss and costs associated with cake } \\
\text { transportation by trucks to a field } \\
\text { moisture and the volume of cake transported to a field }\end{array}$ \\
$\begin{array}{c}\text { Significant loss of thermal energy and water by evaporation in a wet } \\
\text { scrubber due to the high temperature of the flue gas entering the } \\
\text { scrubber }\left(T>160^{\circ} \mathrm{C}\right)\end{array}$ & $\begin{array}{c}\text { Improve the heat transfer efficiency in the pre-air and economizer units } \\
\text { to lower the flue gas temperature and heat losses. Use an additional } \\
\text { heat exchanger to further reduce the temperature of the gas }\end{array}$ \\
\hline
\end{tabular}


technologies. This paper demonstrated, using updated performance indicators, that tightening PM emission standards and the need for compliance with water resource rationalization has made the indiscriminate use of wet scrubbers unfavorable. For a typical sugarcane production unit in Brazil, the mass and energy balances for bagasse combustion and flue gas cleaning were calculated. The following were the main findings:

- The boiler under investigation burned an average of 114.8 $\mathrm{t} / \mathrm{h}$ of bagasse (46.8\% moisture) and produced $544.8 \mathrm{t} / \mathrm{h}$ of flue gases ( $81.7 \%$ dry gases, $18.3 \%$ vapor) and $1.72 \mathrm{t} / \mathrm{h}$ of PM (14.983 kg PM/t bagasse burned);

- The cleaning system handled on average $731,887 \mathrm{~m}^{3} / \mathrm{h}$ of flue gases at $148{ }^{\circ} \mathrm{C}$ with a PM concentration of $1872 \mathrm{mg} / \mathrm{Am}^{3}$ (4133 mg/ $\left.\mathrm{Nm}^{3}\right)$. Under these conditions, the required overall efficiency of the gas cleaning system to meet the ELV $\left(200 \mathrm{mg} / \mathrm{Nm}^{3}\right)$ was $95.2 \%$, a value that other dry cleaning technologies could achieve;

- The wet cleaning system used $387.3 \mathrm{t} / \mathrm{h}$ of water, resulting in a water usage ratio of $3.4 \mathrm{t}$ water/t burned bagasse; however, only $30 \%$ of the total water used in the gas cleaning process was directed toward the wet scrubber. The remaining $70 \%$ was used to aid in the transport of the PM retained in the boiler, heat exchangers, and multicyclone. Such auxiliary water use is unnecessary; eliminating this water use by implementing dry PM conveying methods could save significant capital and operational costs for the WTS;

- The water losses were $27.4 \mathrm{t} / \mathrm{h}$, with $44 \%$ evaporated in the wet scrubber, $20 \%$ conveyed in the moist charash cake, and $36 \%$ lost through periodic drainage of the WTS;

- Wet scrubbing caused a $10.5 \%$ evaporation loss and a 10.2 MW thermal power loss. This energy transferred to water necessitated cooling in the WTS to enable safe water recirculation;

- The water lost in the ash cake would reach 31.1 Mt per season, and the fuel consumption savings would reach US\$33,489 with the use of a dry solids disposal method;

- The WTS accounted for $62 \%$ of the CAPEX of the wet cleaning technology, while the wet scrubber accounted for just $38 \%$. This total cost, not just the scrubber costs, should be used for viability analysis when comparing to other cleaning technologies;

- Improving the collection efficiency of the multicyclone could lead to a further decrease in water use and costs associated with wastewater treatment and with the disposal of solids in the field;

- Other optimization alternatives are proposed, including replacing the scrubbing technology with Venturi scrubbers, improving the solid-liquid separation to reduce the ash cake moisture and increasing the heat transfer effi- ciency in the pre-air and economizer units to reduce the heat losses.

Supplementary Information The online version contains supplementary material available at https://doi.org/10.1007/s10098-021-02139-3.

Acknowledgements The authors would like to thank CNPq-Brazilian National Research Council (Process 307259/2018-81). FG. Lovero also expresses gratitude for the M.S. scholarship.

Funding Open access funding provided by Politecnico di Torino within the CRUI-CARE Agreement.

Open Access This article is licensed under a Creative Commons Attribution 4.0 International License, which permits use, sharing, adaptation, distribution and reproduction in any medium or format, as long as you give appropriate credit to the original author(s) and the source, provide a link to the Creative Commons licence, and indicate if changes were made. The images or other third party material in this article are included in the article's Creative Commons licence, unless indicated otherwise in a credit line to the material. If material is not included in the article's Creative Commons licence and your intended use is not permitted by statutory regulation or exceeds the permitted use, you will need to obtain permission directly from the copyright holder. To view a copy of this licence, visit http://creativecommons.org/licenses/by/4.0/.

\section{References}

Allan GN, Fitzgerald JR (1972) Air pollution control for bagasse fired boilers. Proc S Afr Sugar Technol Assoc 46:79-91

Benthum R (2007) Investigation towards the efficiency of a multicyclone dust separator in biomass combustion. Traineeship report WPC 2007.10. 59p. Faculty of Mechanical Engineering, Eindhoven University of Technology

Boshoff TL, Yeo WH (1999) Reduction of bagasse fired boiler stack particulate emission levels. Proc S Afr Sugar Technol Assoc $73: 251-253$

CGEE (2012) Center for Strategic Studies and Management, Sustainability of sugarcane bioenergy_Updated edition 366p-Brasília, DF, Brazil.

CONAMA (2006) National Environmental Council, Resolution no. 382/2006, Annex III, Brazilian Environment Ministry, BrasıliaBrazil (in Portuguese).

CONAMA (2011) National Environmental Council, Resolution no. 436/2011, Annex III, Brazilian Environment Ministry, BrasıliaBrazil (in Portuguese).

Coury JR, Pisani R Jr, Hung YT (2004) Cyclones. Chapter 3. In: Wang LK, Pereira NC, Hung Y-T (eds) Air pollution control engineering, Handbook of environmental engineering, vol 1. Humana Press Inc. Totowa, New Jersey

Das TK (2020) Industrial Environmental management—engineering, science, and policy, 1st edn. Wiley, Hoboken, NJ

EPA (1975) U.S. Environmental Protection Agency. Office of Enforcement. EPA-330/2-75-004, Boiler Stack Emission Monitoring, Kekaha Sugar Company. National Enforcement Investigations Center, Denver, Colorado

EPA (1995) U.S. Environmental Protection Agency, 1995. AP-42: Compilation of Air Pollution Emission Factors. Volume I: Stationary Point and Area Sources. Appendix B.1 Particle size distribution data and sized emission factors for selected sources, 5th 
edn, U.S. Environmental Protection Agency, Office of Air Quality Planning and Standards, Research Triangle Park

EPA (2002) U.S. Environmental Protection Agency, EPA Air pollution control cost manual, 6th edn, 752p. EPA/452/B-02-001, Office of Air Quality Planning and Standards Research, Triangle Park, North Carolina

EPE (2018) Empresa de Pesquisa Energética, Brazilian Energy Balance 2018 Year 2017, Rio de Janeiro

FAO (2019) FAOSTAT. Food and Agriculture Organization of the United Nations, Rome, Italy 2019. Crops production worldwide (sugarcane). http://www.fao.org/faostat/en/?\#data/QC/visualize. Accessed 22 Jun 2019

Flood BW, Frew R (1974) Fly ash collectors for bagasse fired boilers. Proc Qld Soc Sugar Cane Technol Conf 41:143-149

Fuess LT, Garcia M (2014) Implications of stillage land disposal: A critical review on the impacts of fertigation. J Environ Manag 145:210-229

GAIN-USDA-FAS (2018) Global Agricultural Information Network United States Department of Agriculture-Foreign Agricultural Service. GAIN Report number BR 18004: Brazil Sugar Annual. https://gain.fas.usda.gov/Recent\%20GAIN\%20Publications/ Sugar\%20Annual_Sao\%20Paulo\%20ATO_Brazil_4-13-2018. pdf. Accessed 13 Apr 2018

Heidenreich S (2013) Hot gas filtration-a review. Fuel 104:83-94

Inkson M, Misplon B, Villiers E (2010) EPA Challenges for bagassefired power stations. In: 27 th congress of the international society of sugar cane technologists

Jaworek A, Jędrusik M, Świerczok A, Czech T, Sobczyk AT, Lackowski M (2011) Biomass co-firing-new challenge for electrostatic precipitators. Int J Plasma Environ Sci Technol 5(2):161-167

Innocentini MDM, Paula NA, Latanze R (2011) Method for reducing the volume of vinasse by making use of the energy potential of combustion gases generated from biomass combustion in boilers WO2012092652A1, 2011. (Brazilian Patent PI-1100004-0).

IRENA (2019) Sugarcane bioenergy in southern Africa: economic potential for sustainable scale-up. International Renewable Energy Agency, Abu Dhabi

Khoodaruth A (2014) Optimisation of a cogenerated energy systems: the cane biomass flexi-factory case study. Energy Procedia 62:656-665

Lora EES, Hervas I (1999) Air pollution control in the sugarcane industry. Proc Int Soc Sug Cane Technol 23:323-332

Lovero FG (2017) Evaluation of ceramic-based technologies for emission control systems operating in typical Brazilian sugarcane processing plants. Master's degree course in Energy and Nuclear Engineering. Politecnico di Torino, Italy

Mann A (2017) Improved modelling of wet scrubbers, Final Report 2012/055-Sugar Research Australia Ltd

McGivney W, Kawamura S (2008) Cost estimating manual for water treatment facilities. Wiley, Hoboken

Moor BSTC (2007) Flue gas scrubbing equipment for bagasse fired boilers. Proc Int Soc Sugar Cane Technol 26:1273-1283

Moreira JR (2007) Water use and impacts due to ethanol production in Brazil. International Conference on Linkages in Energy and Water Use in Agriculture in Developing Countries, Organized by
IWMI and FAO, ICRISAT, India, January http://www.iwmi.cgiar. org/EWMA/files/papers/Jose_Moreira.pdf. Accessed 18 Dec 2020

NETL (2011) National Energy Technology Laboratory, Quality Guidelines for Energy Systems Studies: Cost Estimation Methodology for NETL Assessments of Power Plant Performance, U.S. department of Energy, April 2011

Peng L, Jackson PA, Li QW, Deng HH (2014) Potential for bioenergy production from sugarcane in China. BioEnergy Res 7(3):1045-1059

Rein P (2007) Cane sugar engineering. Verlag Dr Albert Bartens KG, Berlin

Rosendahl L (ed) (2013) Biomass combustion science, technology and engineering. Woodhead Publishing Limited, Cambridge

Sahu O (2018) Assessment of sugarcane industry: suitability for production, consumption, and utilization. Ann Agrar Sci 16:389-395

Sahu SK, Ohara T, Beig G, Kurokawa J, Nagashima T (2015) Rising critical emission of air pollutants from renewable biomass based cogeneration from the sugar industry in India. Environ Res Lett 10:095002

Singh R, Shukla A (2014) A review on methods of flue gas cleaning from combustion of biomass. Renew Sustain Energy Rev 29:854-864

Sosa-Arnao JH, Nebra SA (2009) Bagasse dryer role in the energy recovery of water tube boilers. Dry Technol 27:587-594

Stone KC, Hunt PG, Cantrell KB, Ro KS (2010) The potential impacts of biomass feedstock production on water resource availability. Biores Technol 101:2014-2025

Teixeira FN, Olivares-Gómez E, Lora EES, Sauvanell ALB (2007) Characterisation of polluting emissions from sugarcane bagasse boilers and their removal. Proc Int Soc Sugar Cane Technol 26:1354-1363

Tsiropoulos I, Faaij APC, Seabra JEA, Lundquist L, Schenker U, Briois JF, Patel MK (2014) Life cycle assessment of sugarcane ethanol production in India in comparison to Brazil. Int $\mathrm{J}$ Life Cycle Assess 19:1049-1067

Turton R, Shaeiwitz JA, Bhattacharyya D, Whiting WB (2018) Analysis, synthesis, and design of chemical processes, 5 th edn. Pearson Education Inc, Upper Saddle River

Xiao G, Wang X, Zhang J, Ni M, Gao X, Luo Z, Cen K (2013) Granular bed filter: a promising technology for hot gas clean-up. Powder Technol 244:93-99

Zhang C, Wang H, Bai L, Wu C, Shen L, Sippula O, Yang J, Zhou L, He C, Liu J, Ristovski Z, Morawska L, Wang B (2020) Should industrial bagasse-fired boilers be phased out in China? J Clean Prod 265:121716

Zhao D, Li YR (2015) Climate change and sugarcane production: potential impact and mitigation strategies. Int J Agron Article ID 547386. https://doi.org/10.1155/2015/547386

Yive NSCK, Tiroumalechetty M (2008) Dioxin levels in fly ash coming from the combustion of bagasse. J Hazard Mater 155:179-182

Publisher's Note Springer Nature remains neutral with regard to jurisdictional claims in published maps and institutional affiliations. 